\title{
A Rare Cause of Abdominal Mass: Rapunzel Syndrome
}

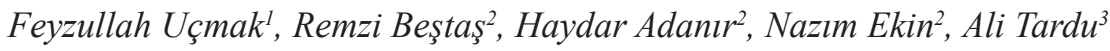

\begin{abstract}
Bezoar is a condition in which foods or fibers that are not absorbed in the gastrointestinal system usually accumulate in the stomach. It usually develops in persons with gastrointestinal motility disorders, anatomic changes or psychiatric disorders. Trichobezoar is the accumulation of hair in the gastric chamber among people with psychiatric disorders such as trichotillomania and trichophagia. Rapunzel syndrome, however, is a rare form of trichobezoar extending from the stomach to the small intestine. In this paper, we present a rare case of 15-year old girl diagnosed with Rapunzel syndrome on admission due to abdominal pain and abdominal mass. J Clin Exp Invest 2016; 7 (1): $87-90$
\end{abstract}

Key words: Rapunzel syndrome, trichobezoar, abdomen mass

\section{Karında Kitlenin Nadir Bir Sebebi: Rapunzel Sendromu}

\section{ÖZET}

Bezoar gastrointestinal sistemden emilemeyen gıdalar veya fiberlerin sıklıkla midede birikmesi sonucunda oluşmaktadır. Genellikle gastrointestinal sistemin motilite bozukluğu, anatomik değişiklik varlığı veya psikiyatrik rahatsızlığı olanlarda rastlanmaktadır. Trikobezoar genellikle trichotillomania, trichophagia gibi psikiyatrik rahatsızlığı olanlarda mide içinde saç birikimidir. Rapunzel sendromu ise trichobezoarın mideden ince barsaklara geçiş göstermesi sonucu oluşan nadir bir durumdur. Bu yazıda karın ağrısı ve karında kitle şikayetiyle başvuran 15 yaşındaki bir kız çocuğunda saptanan Rapunzel sendromu tanısı koyduğumuz nadir olgumuzu sunacağız.

Anahtar kelimeler: Rapunzel sendromu, trikobezoar, karında kitle

\section{INTRODUCTION}

The word bezoar comes from the Persian 'Bedzahr", which literally means antidote to poison [1]. The types of bezoar include trichobezoar (formed from hair), phytobezoars (formed from vegetable and fruit materials), lactobezoars (indigested milk) and food boluses composed of food items that cannot be digested. Trichobezoar is the most common type of bezoar. Unlike the other bezoar types, trichobezoars most commonly affect women in their second decade of life in the presence of an underlying psychiatric disorder [2]. Rapunzel syndrome is a rare form of trichobezoar extending from the stomach to the small intestine. It was first described by Vaughenet al. in 1968 [3].

\section{CASE}

A 15-year old girl was admitted to our clinic with complaints of abdominal pain mainly in the epigastric area and swollen abdomen in the last six months. The patient history included lack of appetite and weakness, whereas she did not suffer from vomiting, diarrhea, weight loss and fever. Physical examination of the patient showed sensitivity in the epigastric area and a regular-bordered, movable and painless mass of $14 \times 10$ $\mathrm{cm}$ extending from the epigastric area to the right lower quadrant of abdomen. Defense and rebound in the abdomen was not noted, while the bowel sounds were normal. Dermatologic examination showed nonscarring local alopecic area up to $6 \mathrm{~cm}$ in diameter in the right occipital region. Laboratory tests resulted in no findings other than iron deficiency anemia ( $\mathrm{Hb} 8 \mathrm{~g} /$ $\mathrm{dl}$ (reference range 12.5-16), serum iron $12 \mu \mathrm{g} / \mathrm{dl}$ (reference range 37-145), iron binding capacity $211 \mu \mathrm{g} /$ $\mathrm{dl}$ (reference range 110-370)). Contrast abdominal tomography that was performed due to abdominal mass showed a mass the thickest part of which reached up to $5 \mathrm{~cm}$, which had the density value of 10-15 HU in the

\footnotetext{
${ }^{1}$ Department of Gastroenterology, Faculty of Medicine, Dicle University, Diyarbakir, Turkey

${ }^{2}$ Department of Gastroenterology, Diyarbakir Education and Research Hospital, Diyarbakir, Turkey

${ }^{3}$ Department of General Surgery, Diyarbakir Education and Research Hospital, Diyarbakir, Turkey
}

Correspondence: Feyzullah Uçmak,

Department of Gastroenterology, Faculty of Medicine, Dicle University, Diyarbakir Turkey Email: ucmakfeyz@gmail.com

Received: 15.09.2015, Accepted: 20.01.2016

Copyright (C) JCEI / Journal of Clinical and Experimental Investigations 2016, All rights reserved 
heterogeneous internal structure and which filled the stomach lumen (Figure 1).

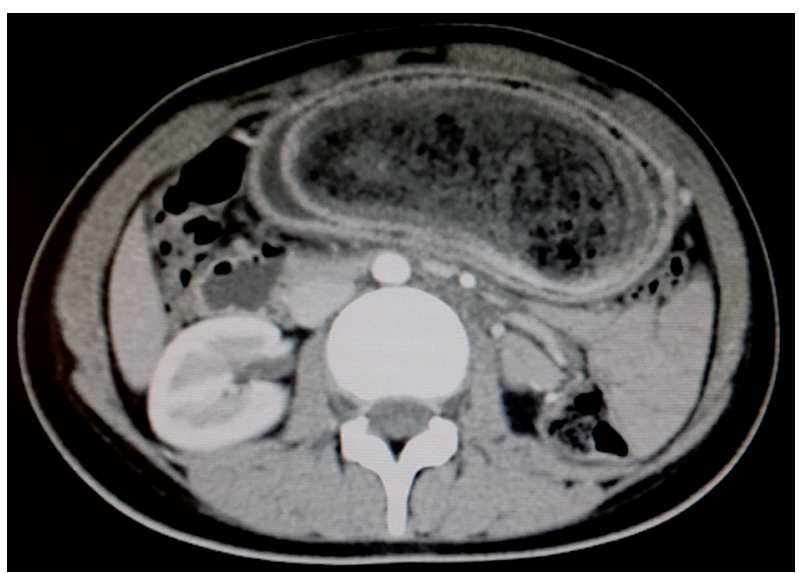

Figure 1. Abdomen CT scan demonstrating heterogenous stricture filling the stomach
Endoscopy showed a hair concretion filling the stomach lumen and extending from the pylorus to the duodenum and a 2-cm ulcer in the gastric corpus (Figure 2a-b). After the endoscopy, her father told that the case had been eating hair since she was 3 years old. Based on these findings, she was diagnosed as Rapunzel syndrome.

Two units of blood were transfused to the patient and the gastrotomy operation was performed on the following day to remove the trichobezoar material weighing 760 grams and extending from the stomach through the pylorus to the duodenum (Figure 3). Following the requested psychiatry consultation, $50-\mathrm{mg} /$ day sertraline treatment was initiated on suspicion of trichotillomania and the patient was asked to visit the policlinic regularly for the follow-up. The patient was discharged on day eight following the operation as no complications developed.

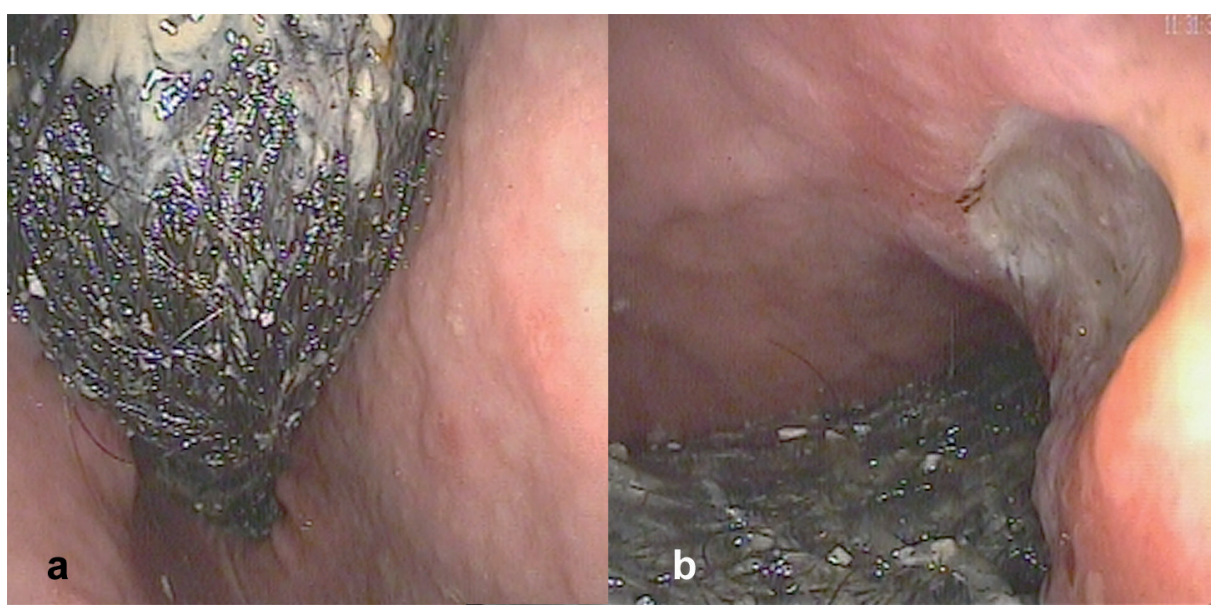

Figure 2 a-b. Endoscopy showing a giant trichobezoar with extending beyond the pylorus (a) and secondary ulceration in the corpus (b)

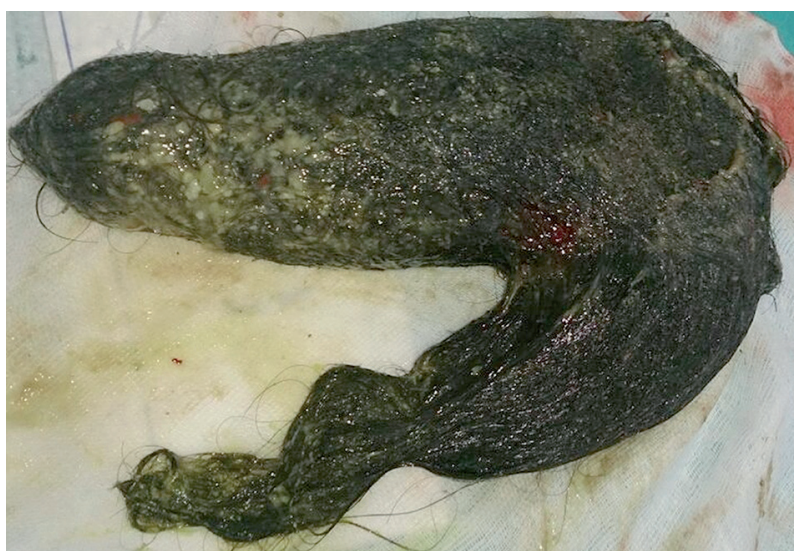

Figure 3. Postsurgical specimen demonstrating a large body in the configuration of the stomach with a tail extending into the duodenum

\section{DISCUSSION}

Rapunzel is the main character of a fairy tale written by Grimm brothers who were important authors of German literature. Rapunzel was confined by a witch in a castle and had a very long golden hair that could extend from the tower to the round. Trichobezoar is the most common type of bezoar that is formed of hair and hair-like fibers. Trichobezoar most commonly occurs in people with underlying psychiatric disorders such as trichotillomania and trichophagia. Bouweret al. reported that only $1 \%$ of the trichotillomania patents required surgical intervention due to the habit of eating hair [4]. Hair strands are presumed to be retained in the gastric mucosal folds in the beginning because they are too slippery to be propulsed and become like 
a mesh after a while. Protein denatures due to acid; therefore, trichobezoars are usually black. On the other hand, the retained mucus make the trichobezoars glisten and degradation of food residue trapped within it lead to foul smelling [5]. Trichobezoars are more common in countries where women grow their hair as a tradition. All but one case with Rapunzel syndrome reported in the literature were female like our patient. The cause of trichobezoar in the only male case was his sister's hair [6].

Although people are affected from this syndrome, they occasionally remain asymptomatic for many years. Only when the bezoar enlarges in the extent to cause obstruction, then the symptoms develop. It most commonly presents with abdominal pain, nausea and vomiting, obstruction, and peritonitis. The less common symptoms of the patients include weight loss, anorexia, hematemesis [6]. Gastric ulceration, obstructive jaundice, acute pancreatitis, intestinal intusseptions are the complications caused by a large eroding or obstructing bezoar [6]. Protein-losing enteropathy, iron deficiency, and megaloblastic anemia are the other malabsorption-related complications [7]. Our patient also had iron deficiency anemia and gastric ulcer that was found both during endoscopic and surgical procedure.

The methods used for diagnosis are the radiological examinations such as barium radiographies, USG, abdominal computed tomography and endoscopy. Among the radiological imaging methods, computed tomography has the highest accuracy in diagnosis. CT scan shows a regular-bordered lesion in the region of stomach, which is formed of concentric whorls of different densities with pockets of air enmeshed within it [8]. The more peripheral interstices of the lesion are filled by oral contrast and a thin band of contrast surrounds it. Neoplastic lesion cannot be detected due to the absence of significant post intravenous contrast enhancement [9]. The golden standard for diagnosis is the endoscopy with its pathognomonic image [7]. Its additional advantages are that it allows treatment of eligible cases during the procedure and it can also be used in pregnant women.

The goal of the trichobezoar treatment is to remove the bezoar and prevent recurrence. Varying rates of success have been reported for the use of non-invasive methods such as intragastric enzyme administration (pancreatic lipase, cellulose) and use of medications (metoclopramide, acetylcholine) [7]. Bezoar can be removed by endoscopy or surgery. Endoscopic treatment is possible during the asymptomatic period when the trichobezoar is small in size [7]. Endoscopic methods must be avoided in case of a large sized trichobezoar and Rapunzel syndrome due to the risk of airway obstruction during the procedure [10]. Laparotomic surgery is indicated for extremely large and solid thrichobezoars that might lead to haemorrhage and perforation and Rapunzel syndrome. Minimally invasive techniques and laparoscopic surgery are the other options for the treatment of small-medium sized bezoars. Our patient was treated successfully by gastrotomy through a mid-line laparotomy approach.

The disease was observed to relapse in cases that did not receive a long-term psychiatric support after surgery [11]. In order to reduce recurrence, long-term psychiatric follow-up should be advised with the support of family members or the spouse.

In conclusion, trichobezoar should be kept in mind as a differential diagnosis of young girls admitted with the complaint of abdominal mass. Early diagnosis and treatment of Rapunzel syndrome in cooperation with a gastroenterologist, dermatologist, general surgeon, radiologist and psychiatrists important due to the potential development of mortal complications. Psychiatric treatment and follow-up is as important as surgical treatment to prevent relapses.

Declaration of Conflicting Interests: The authors declare that they have no conflict of interest.

Financial Disclosure: No financial support was received.

\section{REFERENCES}

1. Williams RS. The fascinating history of bezoars. Med J Aust 1986;145:613-614.

2. DeBakey M, Ochsner A. Bezoars and concretion: Comprehensive review of literature with analysis of 303 cases and presentation of 8 additional cases. Surgery 1939;4:132-210.

3. Vaughan ED Jr, Sawyers JL, Scott HW. The Rapunzel syndrome. An unusual complication of intestinal bezoar. Surgery 1968;63:339-343.

4. Bouwer C, Stein DJ. Trichobezoars in trichotillomania: case report and literature overview. Psychosom Med 1998;60:658-660.

5. Lamerton AJ. Trichobezoars: Two case reports - a new physical sign. Am J Gastroenterol 1984;79:354-356.

6. Naik S, Gupta V, Naik S, et al. Rapunzel syndrome reviewed and redefined. Digestive Surgery 2007;24:157-161.

7. Gonuguntla V, Joshi DD. Rapunzel syndrome: A comprehensive review of an unusual case of trichobezoar. Clin Med Res 2009;7:99-102. 
8. Sharma Y, Chhetri RK, Makaju RK, Chapagain S, Shrestha R. Epigastric mass in a young girl: trichobezoar. Imaging diagnosis. Nepal Med Coll J 2006;8:211-212.

9. Morris B, Shah ZK, Shah P. An intragastric trichobezoar: computerized tomographic appearance. J Postgrad Med 2000;46:94-95.
10. Esmaili MR, Abbasi HR, Baradaranfar MH. Respiratory arrest due to airway obstruction following endoscopic removal of Trichobezoar. J Pak Med Assoc 2011;61:700-701.

11. Memon SA, Mandhan P, Qureshi JN, Shairani AJ. Recurrent Rapunzel syndrome - a case report. Med Sci Monit 2003;9:92-94. 